\title{
Low Streamflow Trends in the United States
}

\author{
Gökçe CEYLAN ${ }^{1}$, Upmanu LALL ${ }^{2}$
}

\begin{abstract}
This research considered low streamflow features which are an important indicator of droughts and suggests significant information for water-resources decision making. Consecutive low flow conditions in a river can create chronic water scarcity. Water scarcity is one of the main drivers of a social and economic conflicts. This research has observed not only locations where suitable adaptive management measures are needed but also locations where low flow regime changes due to natural / climate effects or anthropogenic impacts. Trends in low flows in the United States were evaluated using Mann-Kendall and the Sen-Slope trend tests. 5\% significance level is used and an evidence of mostly upward trends in low flows in the United States was found. Trends in referenced (not exposed to anthropogenic impacts) and non-referenced stations (exposed to anthropogenic impacts) were also investigated separately, and then compared. Results illustrate that the percentage of significant low flow trends in non-referenced stations are higher than referenced stations. Furthermore, wavelet, PCA and clustering analysis were also performed. Wavelet analysis was used to determine the amplitude and timing of such low streamflow discontinuities for specific wavebands. Clustering analysis helped to determine a grouping low streamflow patterns with similar annual flow behaviors.
\end{abstract}

Key words: low streamflow, trend analysis, streamflow

\section{Introduction}

\section{Hydrological Drought}

National Oceanic and Atmospheric Administration (NOAA) defines drought as a deficiency in precipitation over an extended period resulting in a water shortage causing adverse impacts on vegetation, animals, and people. Drought is a temporary anomaly from normal climate conditions and may vary significantly by region. Water demand and water management can increase the impact of drought on a particular region. According to NOAA, there are three main types of drought which are meteorological, agricultural and hydrological.

Hydrological Drought is an extended precipitation shortage period that adversely impacts water supplies such as streamflow, reservoir, lake and groundwater. It results significant social impacts. Droughts are one of the costliest weather events in terms of economics and loss of human life (NOAA, 2008). 


\section{Low Flow Hydrology}

Low flow is the minimum flow in a river during the dry season. Low flow is seasonal phenomenon and an indicator of hydrologic droughts. Hydrological drought can be defined as water reduction in reservoirs, lake storage, groundwater levels and streamflow discharge (Smakhtin, 2000).

The ability to predict the occurrence of low flows is critical to the management and operation of reservoirs that often serve multiple, conflicting purposes including water storage and flood control. Trends in low flows could be seen as potential evidence of climate change and the impact of this evidence lead to shifts in the availability of water across the U.S. (Douglas, Vogel, Kroll, 2000). Adaptation to these shifts would be environmentally and economically very costly. Thus, statistical investigation of low flow trends is crucial for proper future adaptations.

\section{Natural and Anthropogenic impacts on low flows}

There are natural and anthropogenic factors which affect low flows. Streamflow is a part of natural system and sensitive to recharge of the system. Precipitation is the major component which plays an important role of recharge (Smakhtin, 2000). Other natural factors which have impacts on the low flow behavior are infiltration characteristics of soils, hydraulic characteristics of aquifers, frequency, rate and the amount of recharge, evapotranspiration rates of basin, vegetation types, topography and climate (Smakhtin, 2000).

Human activities have direct impact on low flow. Examples of these activities are remove/ add water from/to streamflow for agricultural, industrial and municipal purposes. Additionally, irrigation return flows, direct effluent flows to river, inter-basin transfers, and dam construction are also other examples of human activities (Smakhtin, 2000).

\section{Importance of Low Flows}

Low flow is important for water-supply planning, reservoir storage design and planning, irrigation, recreation, and ecological conservation (Smakhtin, 2000). Predicting low flows would be very beneficial to the management and operation of reservoirs. Water managers and decision makers have concerned about possible impacts of the climate variability and human induced climate change on the hydrology of the United States. Furthermore, low flow is an important driver for environmental flow to maintain aquatic and riparian ecosystems. Reduction or augmentation in low flow would change water temperature and concentration levels of solutes. These changes would affect habitat conditions for fish and other biota (Clausen et al., 2004).

Pagano and Garen (2004) states that variations and changes of the climate shift the balance between snow and rainfall and result in changes in streamflow seasonality and create a possibility of an intensified extreme hydrologic events. Therefore, management of natural resources in a climate-induced changing environment could be very challenging. Detecting trends in annual low flows and the magnitude of extreme events could be helpful to managers. 


\section{Determination of Low Flows}

Low flow estimation is made with frequency analysis of flow events from streamflow time series. Smakhtin (2000) claims that widely used low flow characteristics are the magnitudes of annual low flows, variability of flows and the rate of streamflow depletion in the absence of rain, duration of continuous low-flow events, and relative contribution of low flows to the total streamflow hydrograph.

\section{Method}

\section{Data}

Analyses were performed on USGS - Gages II (Geospatial Attributes of Gages for Evaluating Streamflow) data which contains geospatial data and classifications. Gages II provides stream flow values recorded on a daily basis at 9,322 gaging stations across the continental United States. The Gages II contains daily streamflow records collected between 1880 and 2015 (not necessarily continuous or complete).

Gages II is an update to the original Gages and has two distinctive purposes. First purpose is that it provides long flow record data set and the second one is to provide a determination of watersheds which are least disturbed by human influences and other watersheds. Gages which are located at least-disturbed watersheds are called as referenced gages and others are called as non-referenced gages. Providing referenced and non-referenced gages information is very important to achieve the goal of this study. It would help to understand whether low flow regime changes due to natural / climate effects or human activities / anthropogenic impacts (James A. Falcone, 2011). The Gages II based on 12 major eco-regions across the United States. Total number of gaging stations are 9,322 and 2,057 are classified as referenced and 7,265 as non-referenced.
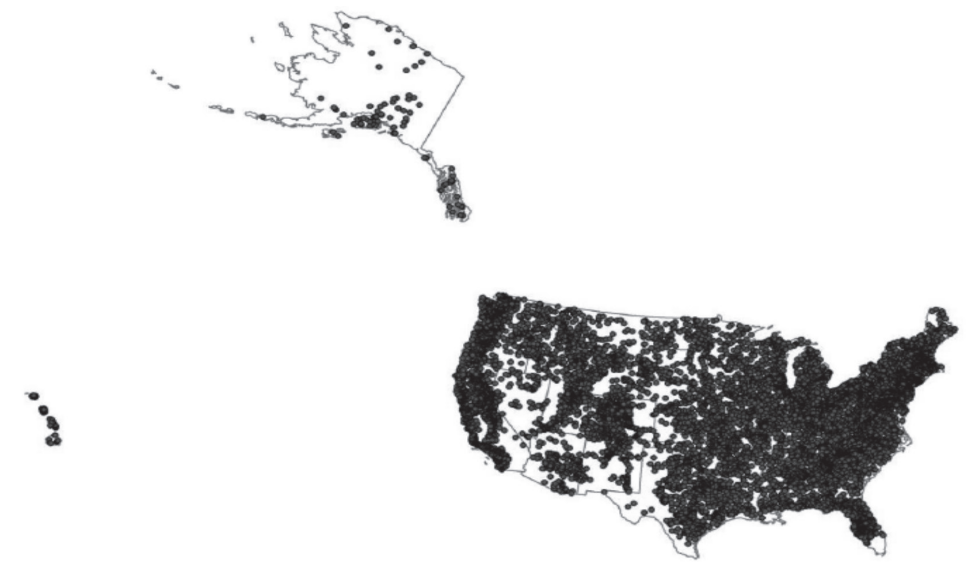

Figure 2.1. Distribution of GAGES II stations in the United States, including Alaska, Hawaii, and Puerto Rico 


\section{Data Analysis}

Data Analysis was performed on Gages II stations with at least 80-year streamflow data and no more than 10 percent missing values. There are 727 Gages II stations which belong to minimum 80 -year of streamflow data with 10 percent missing values. 87 of them are referenced stations and 640 of them are non-referenced stations.

\section{Low flow computation}

U.S. Geological Survey explains that a hydrologically based design flow is defined with the lowest flow event from each year of record. Selecting and identifying an extreme low flow value can be done statistically. In this study, the lowest 7-day average flow and the lowest 30day average low flow in a year were used as characteristics of low flows in streams. 7-day low flow represents annual series of the minimum values of mean discharge over any 7 consecutive days. 30-day low flow represents annual series of the minimum values of mean discharge over any 30 consecutive days. Identification of 7-day and 30-day low flow is very common for water resources design and planning purposes (United States Environmental Protection Agency, EPA).

USGS defines hydrologic regions based on the perimeter of drainage areas which was constituted by the terrain and characteristics of the nature. Defining hydrological regions creates a baseline drainage boundary framework. Regional analysis was performed at hydrologic regions which are determined by USGS, but final results will be given for the whole country in the following sections. Also, not all of the regions meet defined station criteria which is 80 -year streamflow data with 10 percent missing value. Thus, analysis does not cover on all of these determined sixteen regions.

\section{Hypothesis test}

Mann-Kendall trend test was used to perform trend analysis in hydrologic data. Mann-Kendall hypothesis test is a non-parametric test and it determines monotonic change. Normality assumption is not required for this test. However, there must be no serial correlation for the resulting p-values to be correct (USGS, Statistical Methods in Water Resources). It is a rank based method for detecting the presence of trends in time series. Main purpose of the test is to determine whether the median changes over time.

In order to perform the test, streamflow values and time data were used, and then $p$ value and Kendall's were calculated. Trends with $p$ values lower than 0.05 were considered as statistically significant. If $\mathrm{p}$ value is smaller than 0.05 , there is a monotonic trend. The null hypothesis "no trend" was rejected when $p$ is significantly different than zero (larger than 0.05 ).

\section{Wavelet analysis}

Wavelet transforms are used to evaluate surface water resources for water management problems. Signal of a wavelet transform provides time and frequency information (Cannas et al.2005). In this study, wavelet analysis will help to identify annual variability of low flows in 
the United States. All low flow series were standardized, so the global wavelet is comparable. Also, the inter-annual and spatial variability in low streamflow time series based on region can be done with wavelet power spectra assessment.

\section{Clustering analysis}

Basic concept of the cluster analysis is to divide data into relevant groups. This study identifies a groping procedure for low flow patterns that have similar annual low flow behaviors across the country. Low flow variability information is the integrated response of the river basin area, topography, soil type, vegetation and climate. Therefore, grouping gaging stations will provide information about external impacts. Hierarchical clustering was performed on annual low flow data. It is a method of cluster analysis which builds a hierarchy of clusters (Wikipedia/ Cluster analysis). Each connected components in dendogram forms a cluster.

\section{Principal component analysis}

Principle component analysis (PCA) is a tool for analyzing data and identifies patterns in data. Patterns are helpful to understand data groups, unusual records, and dependencies. PCA provides similarities and differences of data set (Smith, 2002). PCA is a statistical procedure which interests in clarifying covariance structure of variables.

It is a method to underline data variation and determine strong patterns in a data set in order to explore and visualize data easily. It identifies the principal directions in which the data varies (Imperial College London, DOC493: Intelligent Data Analysis and Probabilistic Inference Lecture 15).

\section{Results}

\section{Mann-Kendall Trend Test Results}

The results of the MK test for across the United States are given in this section. Mann-Kendall trend test was performed on both referenced and non-referenced stations. Average $p$ values and Sen-Slopes were calculated from historical data at GAGES II referenced and non-referenced stations for the whole country. Only stations that have minimum 80-year data with maximum 10 percent missing values were used during the analysis. According to results, 7 and 30 -days minimum stream flow data show mostly upwards significant trends in the country.

Comparison of referenced and non-referenced stations illustrate 58 percent of the 7-day low flow non-referenced stations show significant trends, while 29 percent of the referenced stations show significant trends. When the same comparison was made for the 30 -day low flow test results, it was found that 31 percent of the referenced stations have significant trends while 59 percent of non-referenced stations show statistically significant trends. 
Figure 3.1 visualizes MK trend test results for all stations with 7 day low flow and Figure 3.2 represents MK trend test results for all stations with 30 day low flow. Blue color represents referenced stations while red ones show non-referenced stations. Filled triangle means related station has a significant trend and unfilled triangles are belong to the stations with non-significant trends. Additionally, direction of a triangle gives information about tendency of the trend (upwards or downwards).

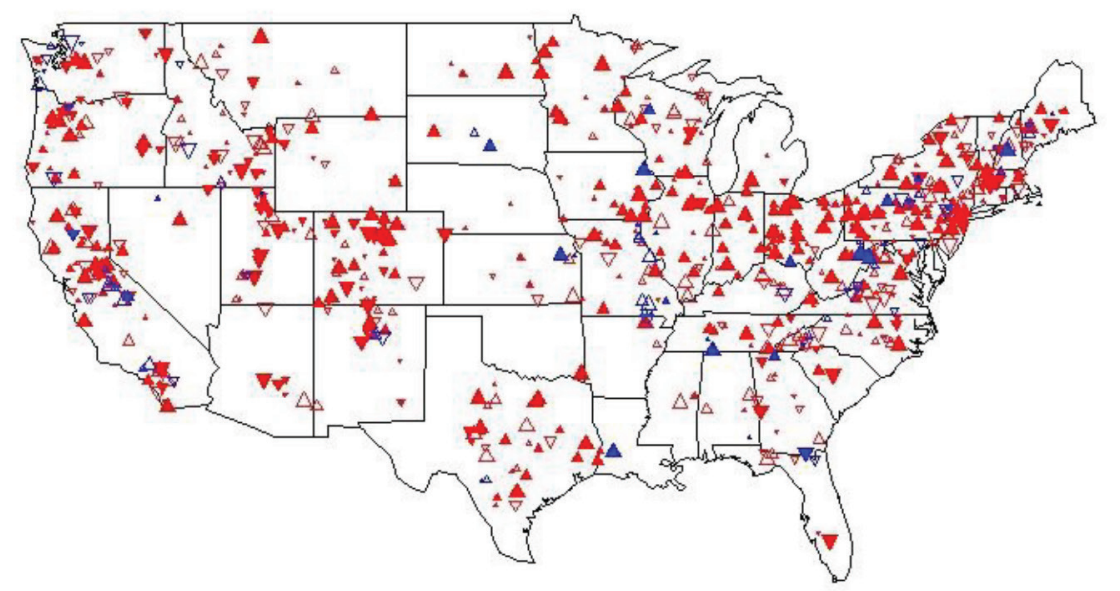

Figure 3.1. 7-day low flow MK Test Results for all stations

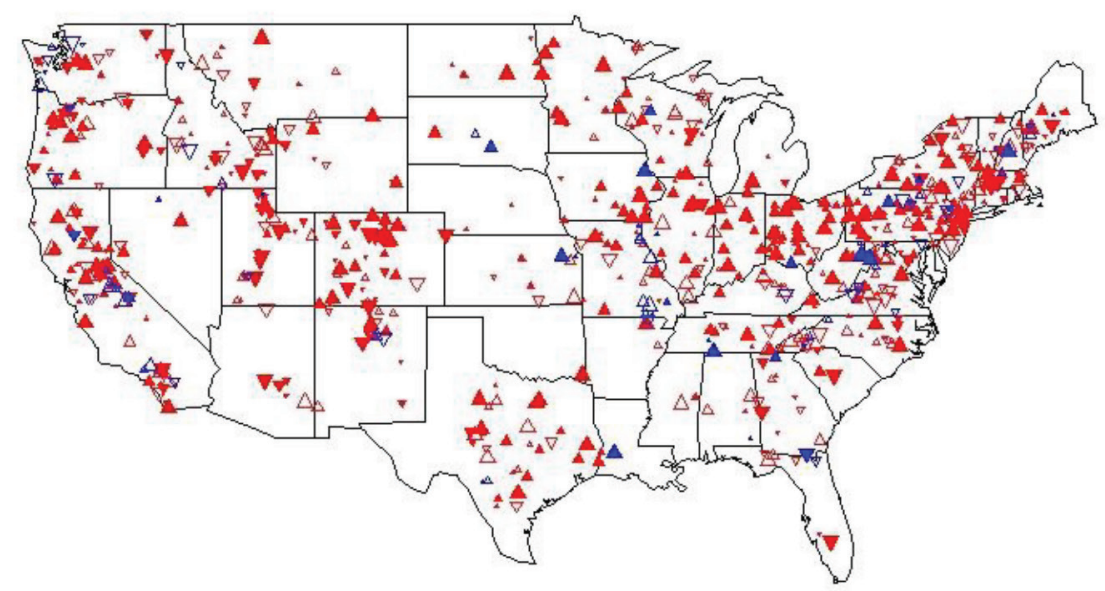

Figure 3.2. 30-day low flow MK Test Results for all stations

As it can be seen from the figures above, MK Trend test results are very close to each other and there is a slight difference between them. 


\section{Clustering Analysis Results}

Cluster analysis was used to divide 7-day annual minimum data set into relevant groups. Therefore, low flow patterns with similar annual low flow behaviors across the country were identified. Clustering results would also lead us to low flow variability information which is the response of the river basin area, topography, soil type, vegetation and climate. 7-day and 30-day annual minimum flows were used to perform clustering analysis. Five main clustering groups based on similar low flow behaviors were detected in all stations for 7-day annual low flows.

\section{7 day all stations clustering map}

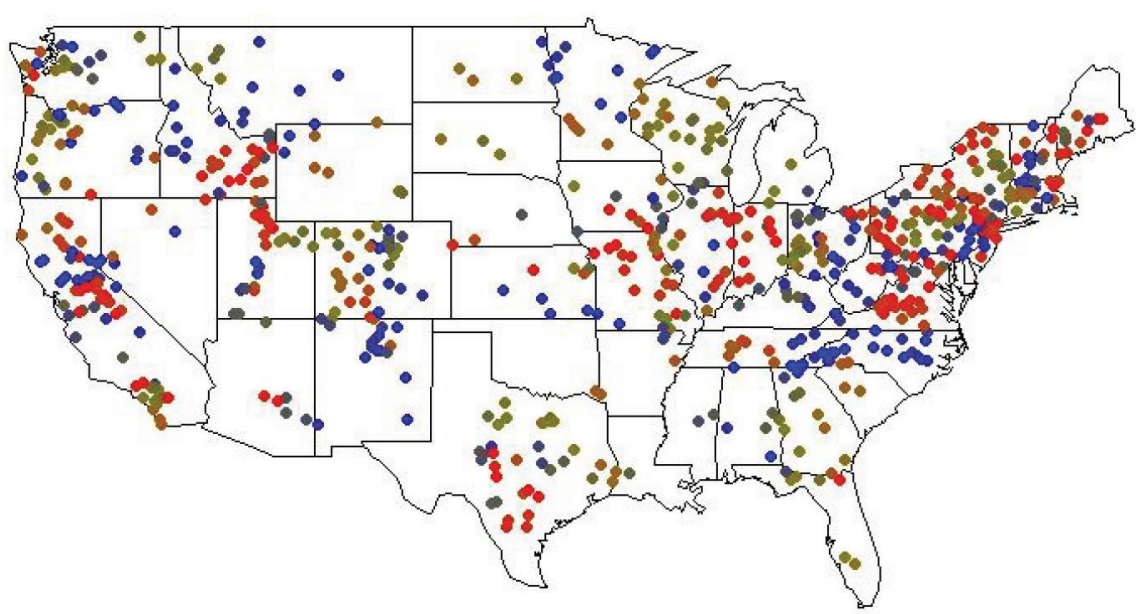

Figure 3.3. 7-day low flow Clustering map for all stations

30 day all stations clustering map

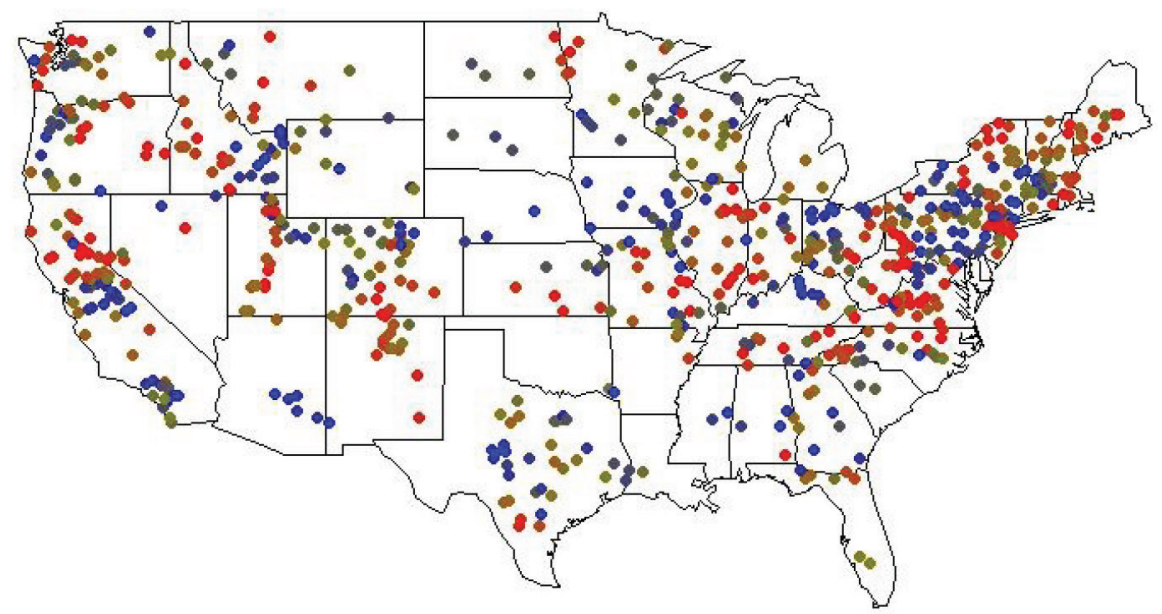

Figure 3.4. 30-day low flow Clustering map for all stations 


\section{Wavelet Analysis and Principle Component Analysis Results}

Wavelet analysis is used to identify and describe variability in annual low streamflow and to gain insights into the dynamical link between the streamflow and both the climate variability and the anthropogenic effects in the country. Principal component Analysis (PCA) was used to construct regional time series to identify links with probable teleconnection pattern time series (Lins, 1985). Low streamflow variation at 727 locations across the United States during the period 1955-2010 were defined by using principal components.

Time series of mean 7-day and 30-day annual streamflow illustrate very different trend behavior for each principal component. The main reason behind these large differences comes from the contribution percentage of components to variance. The highest and the most significant contribution percentage belong to the first component for both 7-day and 30-day flows. Therefore, time series of PC-1 explains the variability accurately.

It is possible to explain the variance in the correlation matrix with the first component regarding to the obtained information from Figure 3.5. and Figure 3.9. . The optimum number of components can be defined as one in this case, because, first component accounts for the maximum possible variance. There is an upward trend in low flows based on the information gathered from the first component (PC-1). This results also supports the obtained results from Mann-Kendall Test.

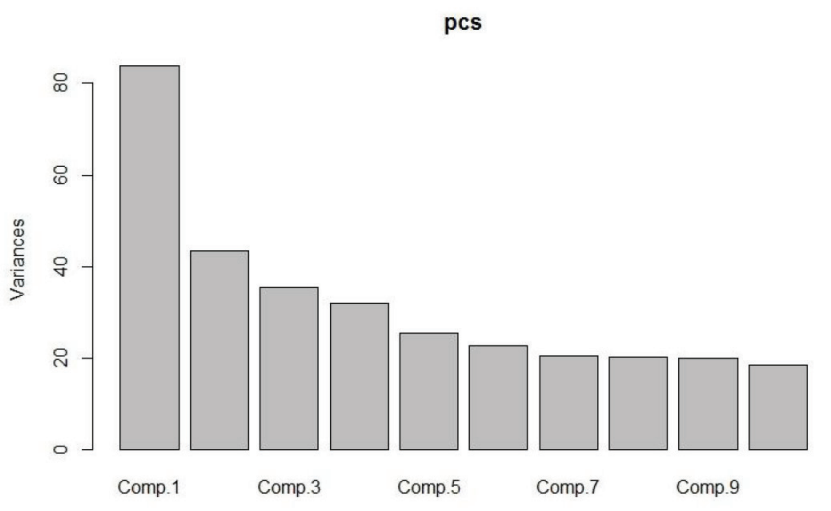

Figure 3.5 Principle Components, 7-day low flow for all stations

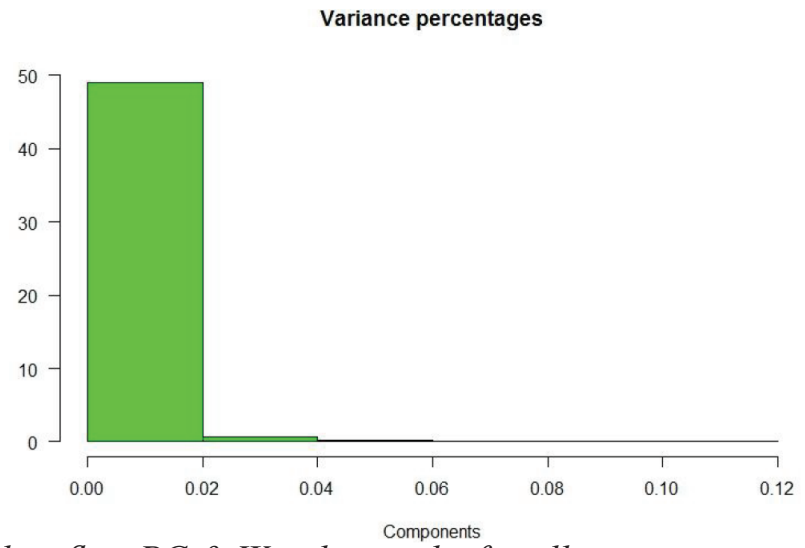

Figure 3.7 7-day low flow PC \& Wavelet results for all stations 

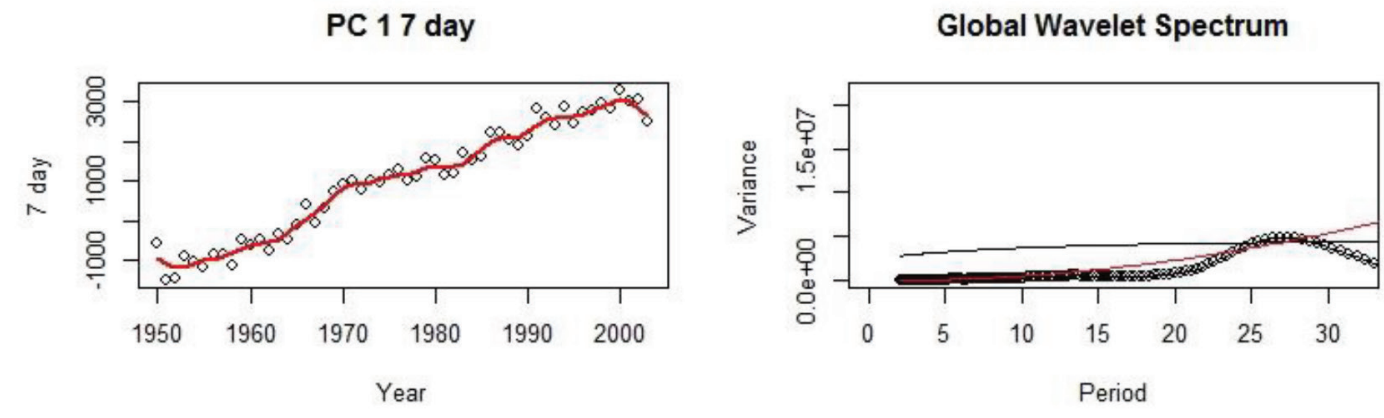

Wavelet -PC 1
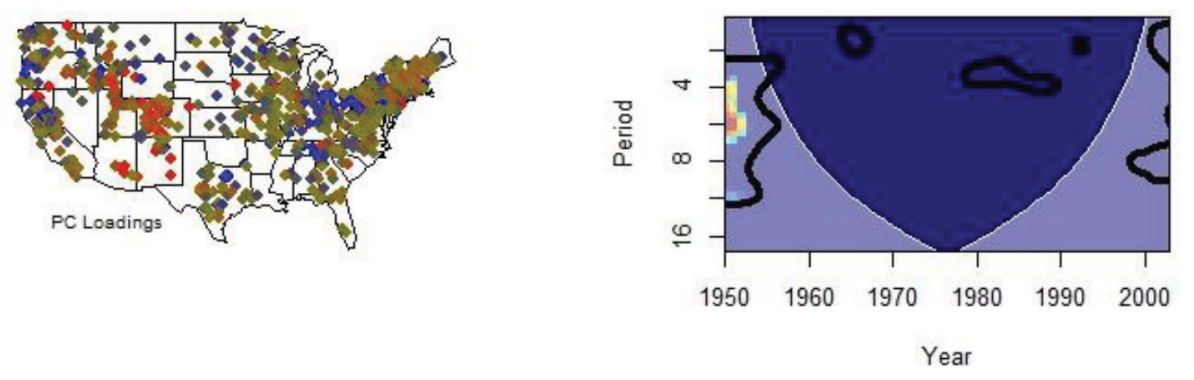

PC 27 day
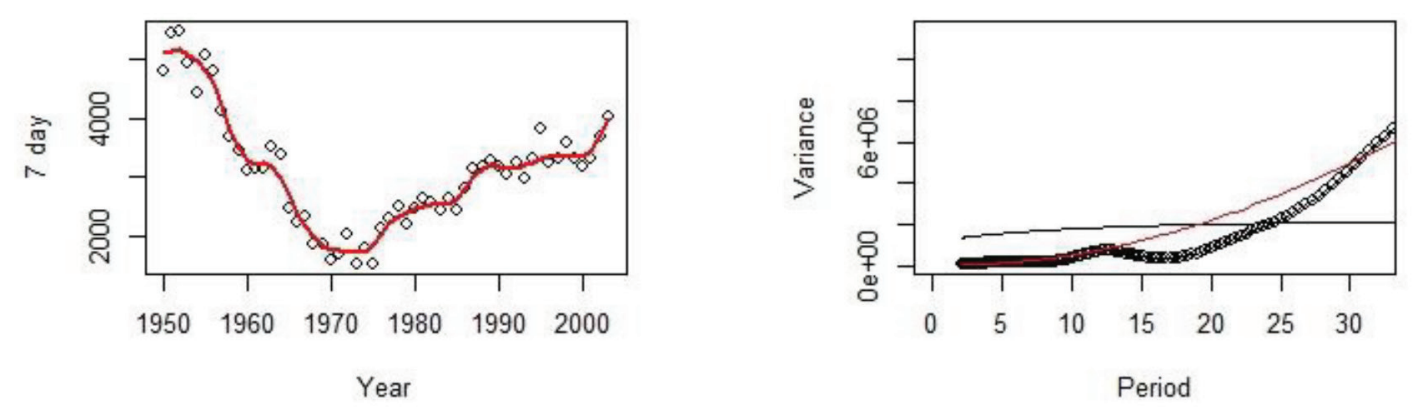

Wavelet -PC 2
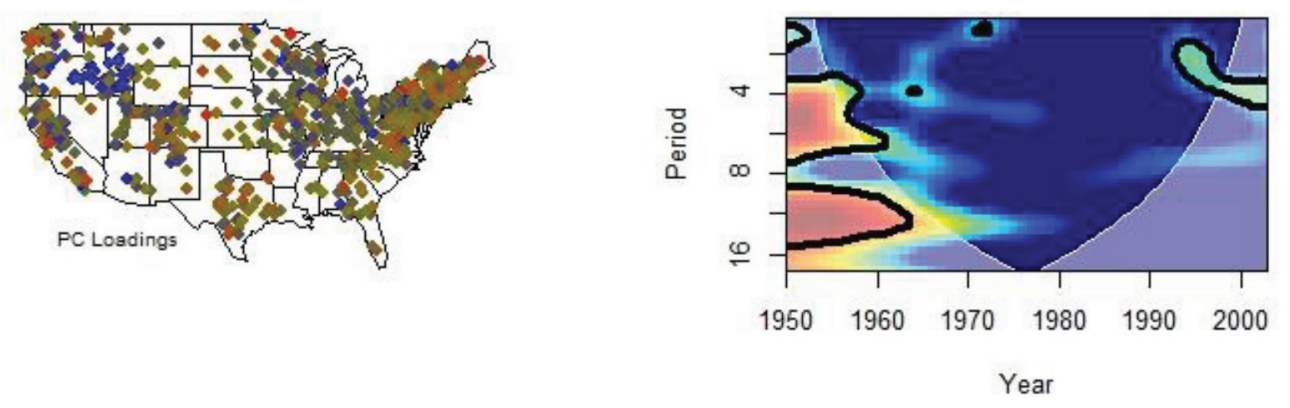

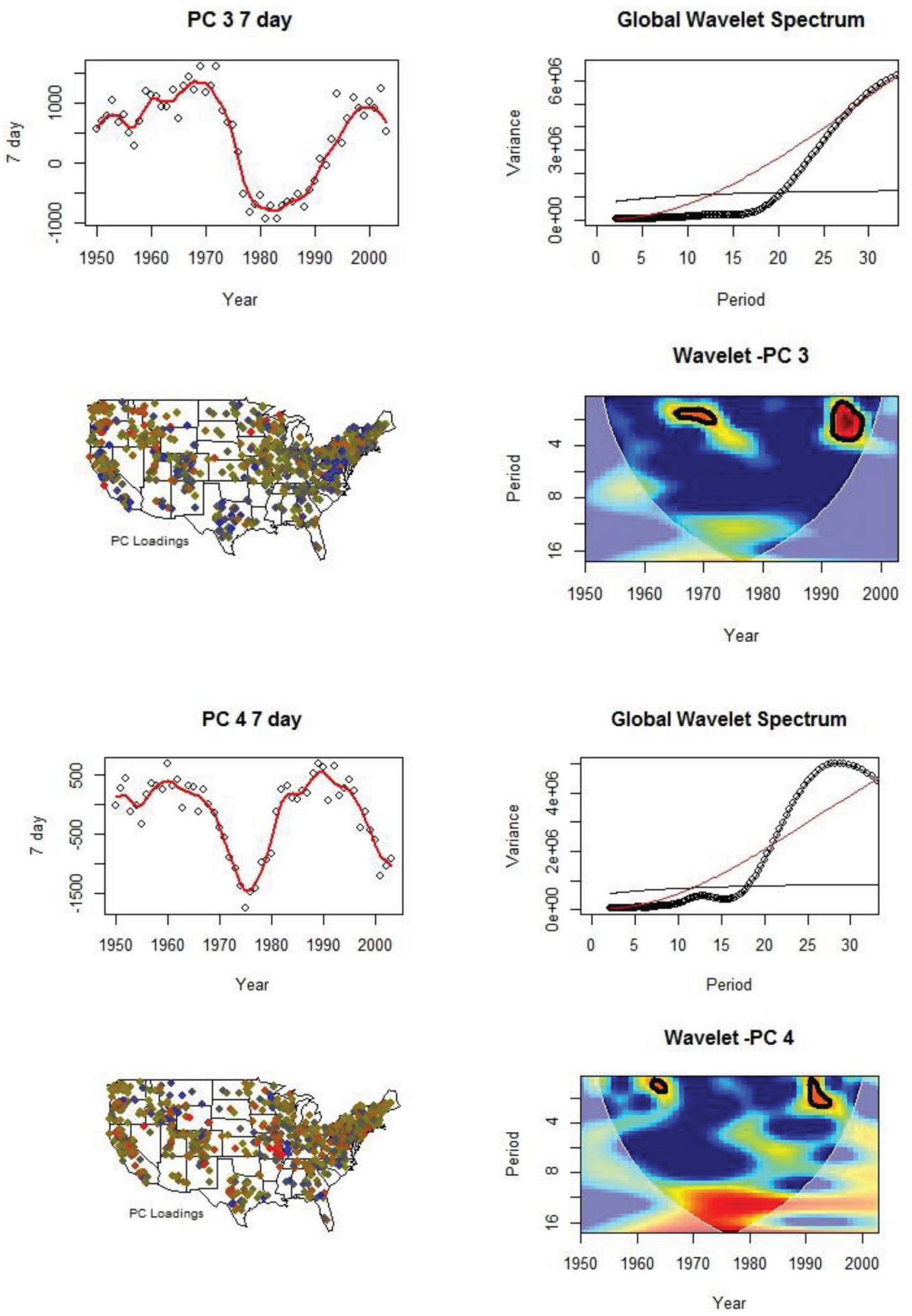

Figure 3.7 7-day low flow PC \& Wavelet results for all stations 

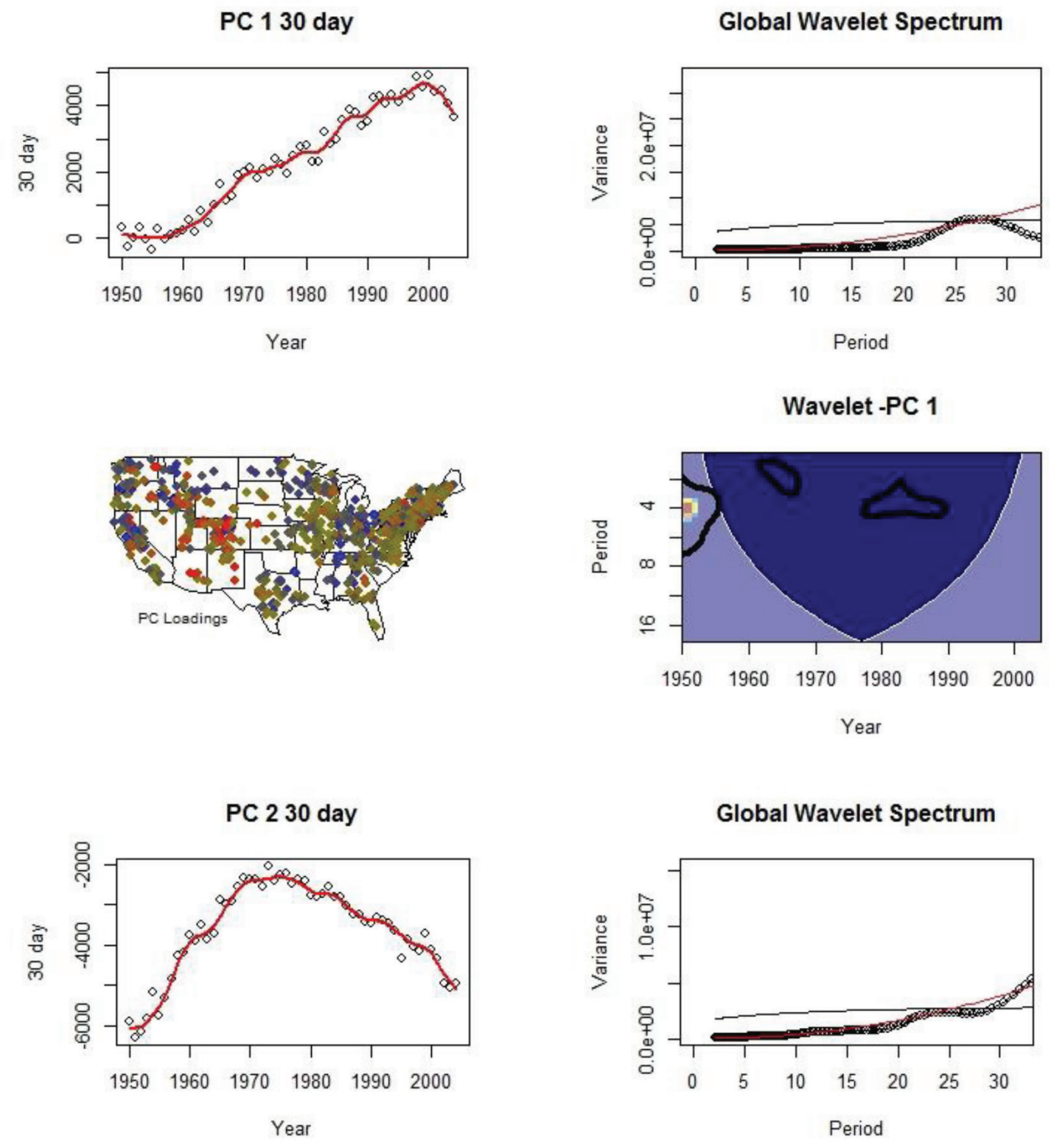

Wavelet -PC 2
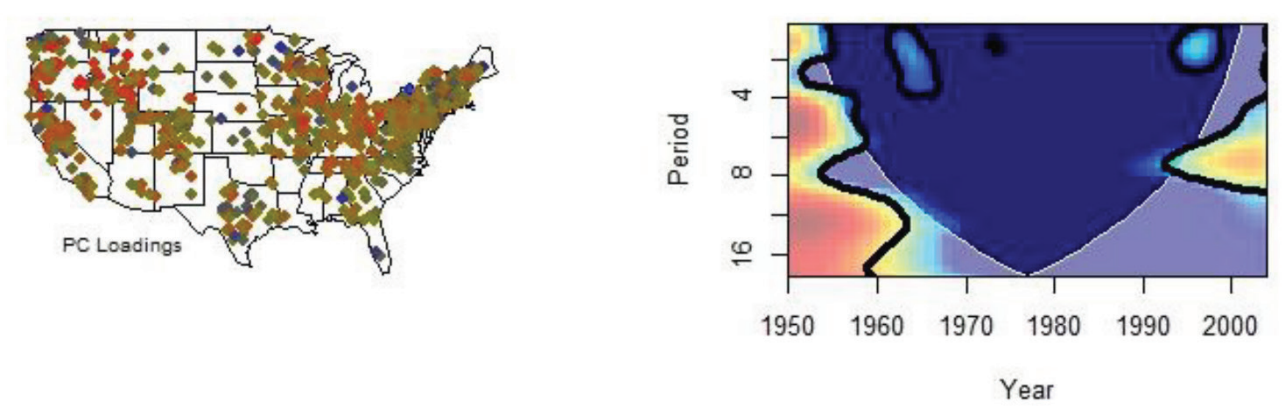

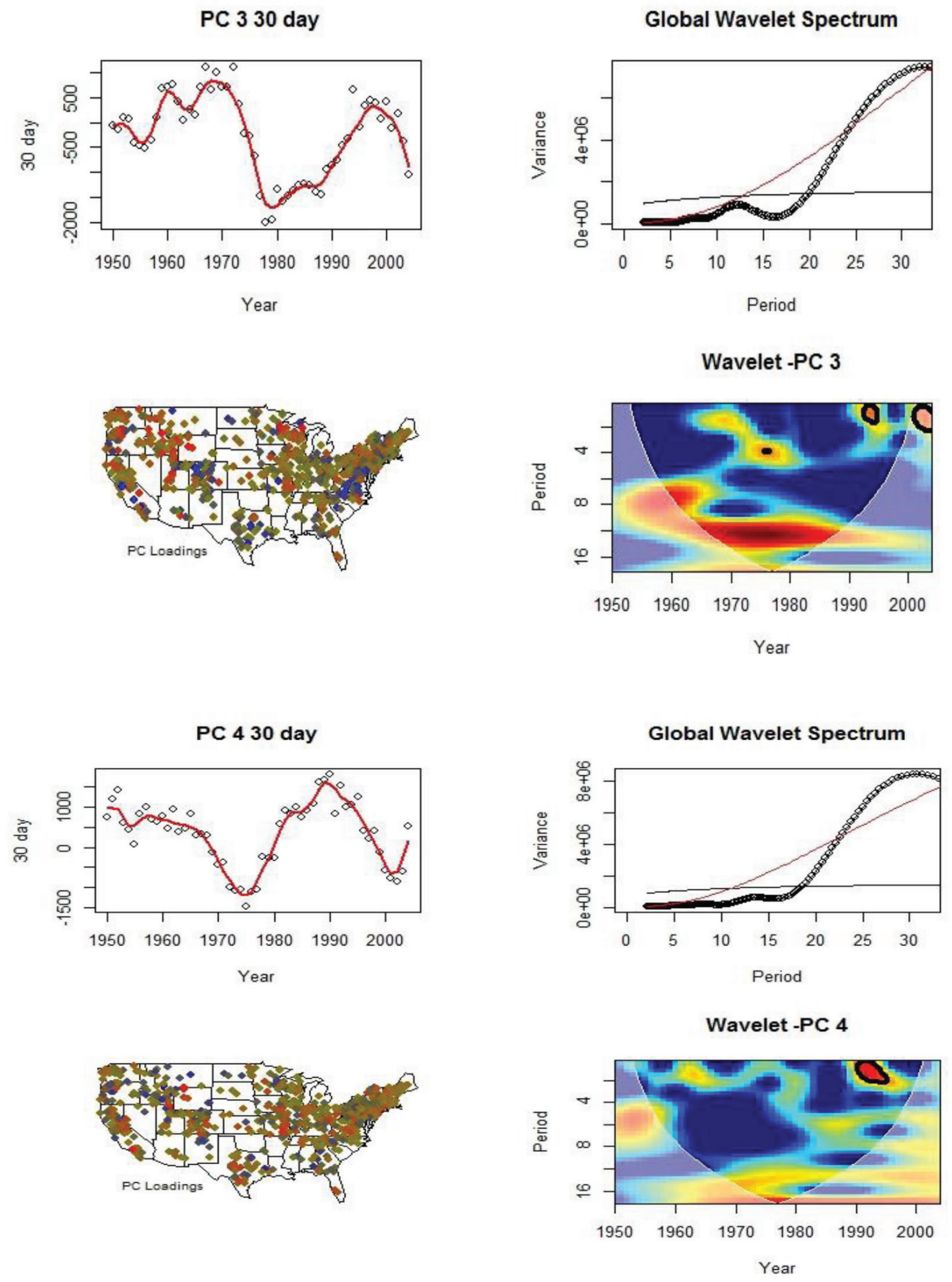

Figure 3.7 7-day low flow PC \& Wavelet results for all stations 
pcs

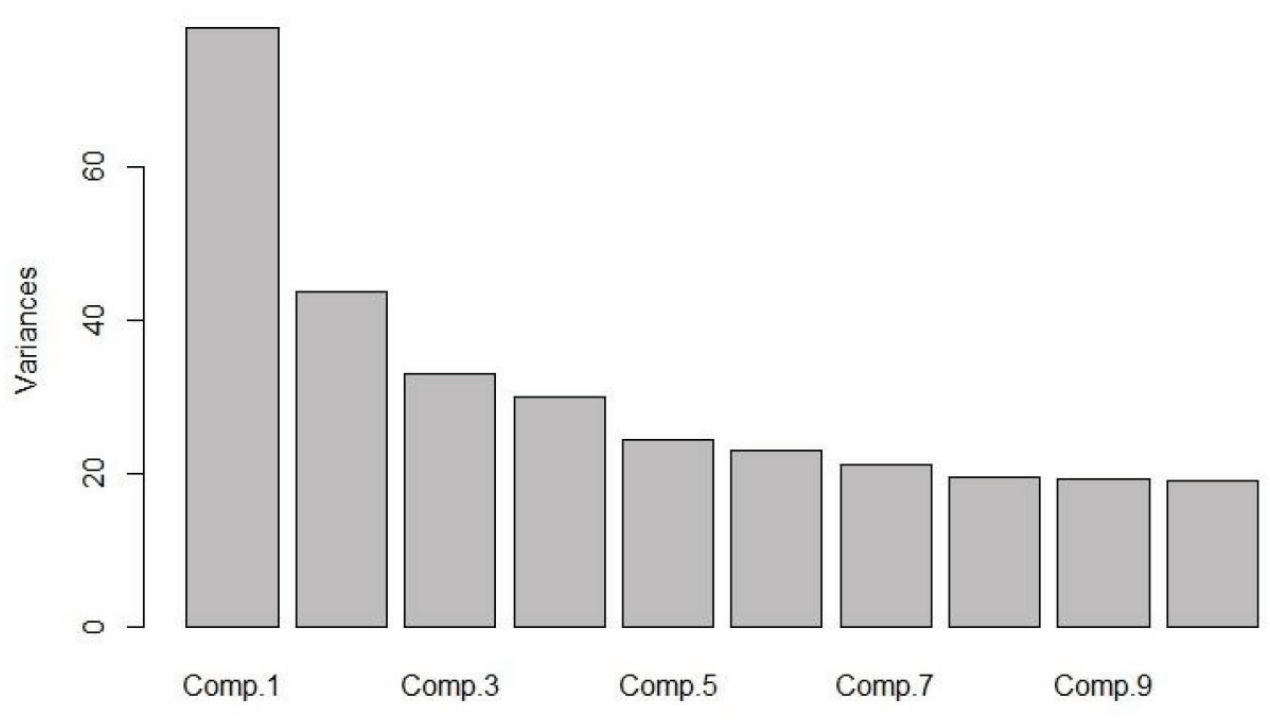

Figure 3.7 7-day low flow PC \& Wavelet results for all stations

\section{Variance percentages}

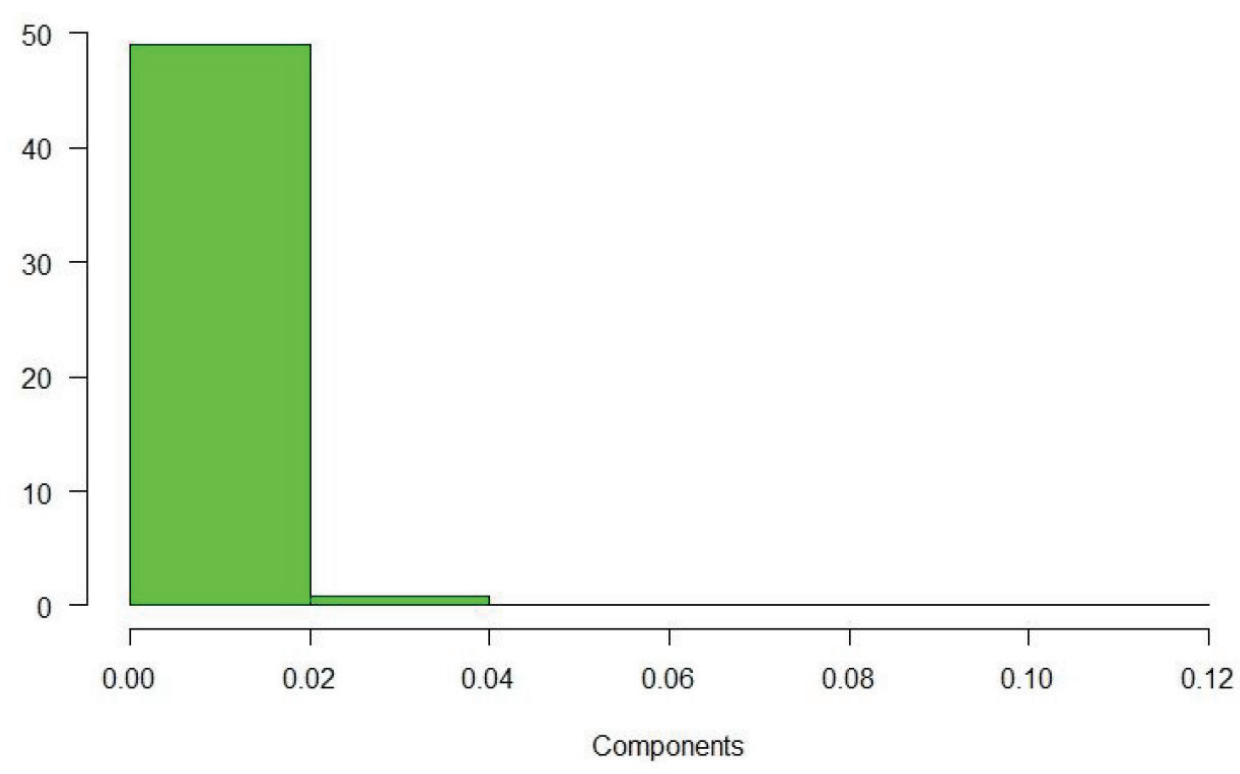

Figure 3.10. Percentage of variance explained, 30-day low flow for all stations 
Trends in low flows were evaluated in the United States by using Mann-Kendall Trend Test and the Sen Slope. Trends were considered statistically significant if the significance was less than 0.05. Statistically significant upward trends in low flows were found in most regions in the United States. Sample size of the referenced stations is pretty low compared to the non-referenced stations. Only number of non-referenced stations is appropriate for a reasonable trend assessment. Therefore, it has been decided to compare these referenced and non-referenced stations with the percentage of their significant trends. 29 percent of referenced stations have significant trends while 58 percent of non-referenced stations have significant trend results based on 7-day low flow data. 26 percent of referenced and 41 percent of non-referenced stations show upward trends in 7-day low flows. There has been found a slight increase in percentage of significant trends when it comes to 30-day low flow. 31 percent of referenced stations have significant trends while 59 percent of non-referenced stations have significant trend results based on 30-day low flow data. 25 percent of referenced stations and 45 percent of non-referenced stations have upward trends in 30-day low flows.

Table 4.1.

Percentages of statistically significant stations

\begin{tabular}{lll}
\hline & Referenced Station \% & Non-referenced Station \% \\
\hline 7 day low flow & 29 & 58 \\
30 day low flow & 31 & 59 \\
\hline
\end{tabular}

Furthermore, cluster analysis was performed to group low streamflow patterns across the United States to detect similar annual flow behaviors. There have been found 5 main groups in 7-day annual low flows and 6 main groups in 30-day annual low flows. Analysis also performed only referenced and non-referenced stations to make a comparison. Referenced stations have more homogeneous distribution of grouping low streamflow patterns.

Lastly, principle component analysis was applied to annually low streamflow observations in order to characterize variability. The highest and the most significant contribution percentage belong to the first component (PC-1) for both 7-day and 30-day flows. Therefore, it is possible to say time series of PC-1 explains the annual low flow variability accurately. There is an upward trend in 7-day and 30-day low flows based on the information gathered from the PC1. This results also supports the obtained results from Mann-Kendall Trend Test and Sen-Slope.

Wavelet spectral shape is determined by the distribution of event time-scales. However, more work is needed to establish the use of wavelets for much accurate and reasonable low streamflow analysis, obtained results suggest that low flows may be classified into distinct categories.

It is also reasonable to identify the correspondence between low flow and climatic changes. Changes in hydrological drought indicators and climate is linked to the behavior of low flows. This research only shows that human disturbed stations have higher significant trends than the least disturbed stations. This provides an evidence that water resources / low streamflow is impacted by environmental change and climate variability. Thus, it is possible to say 
observed trends in low streamflow is affected by human activities. However, there are also climate teleconnection patterns as natural variability and they have possible impacts on low flows. Therefore, naturally occurring teleconnection patterns should also be considered before making a final decision.

\section{References $\Omega$}

Anctil, F., and Paulin, C. (2003). Wavelet Analysis of the Interannual Variability in Southern Que'bec Streamflow. 2004 American Meteorological Society.

Burn, D.H., and Hag Elnur, M.A. (2002). "Detection of hydrologic trends and variability." Journal of Hydrology 255(1-4): 107-122.

Clausen, B., I.G. Jowett, B.J.F. Biggs, and B. Moeslund, (2004). Stream Ecology and Flow Management. In: Developments in Water Science 48, L.M. Tallaksen and H.A.J. Van Lanen (Editors). Elsevier, Amsterdam.

Curran, C.A., Eng K., and Konrad, C.P. (2012). Analysis of low flows and selected methods for estimating low-flow characteristics at partial-record and ungaged stream sites in western Washington: U.S. Geological Survey Scientific Investigations Report 2012-5078.

Helsel D.R, and Hirsch, R.M (2002), Statistical Methods in Water Resources. Techniques of Water-Resources Investigations of the United States Geological Survey.

Dai, A. (2013). Increasing drought under global warming in observations and models. Nature Clim. Change 3(1): 52-58.

Douglas, E. M., et al. (2000). Trends in floods and low flows in the United States: impact of spatial correlation. Journal of Hydrology 240(1-2): 90-105.

EPAWater Data \& Tools (2016). Retrieved from http://waterepa.gov/scitech/datait/models/dflow/flow101.cfm

Flynn, R.H., (2003). Development of regression equations to estimate flow durations and low-flow frequency statistics in New Hampshire streams: U.S. Geological Survey Water- Resources Investigations Report 02.

Imperial College London, DOC493: Intelligent Data Analysis and Probabilistic Inference Lecture 15.

IPCC (2001) Third Assessment Report. Working Group II: Impacts, Adaptation and Vulnerability; Chapter 4: Hydrology and Water Resources. Retrieved from https://www.ipcc.ch/ipc creports/tar/wg2/pdf/wg2TARchap4.pdf 
James A. Falcone, United States Geological Survey, GAGES II (Geospatial Attributes of Gages for Evaluating Streamflow), summary report, September 2011.

Kahya E., Demirel M.C., and Piechota T.C. (2007). Spatial grouping of annual streamflow patterns in Turkey. Hydrology Days 2007.

Kahya, E. and Kalayc1, S. (2004). Trend analysis of streamflow in Turkey. Journal of Hydrology 289(1-4): 128-144.

Kendall, M.G. (1975). Rank correlation methods. Charles Griffin. London. McCabe GJ, Wolock DM (2002) Trends and temperature sensitivity of moisture conditions in the conterminous United States. Climate Research 20.54

Lins, H.F. (1985). "Interannual streamflow variability in the United States based on principal components." Water Resources Research 21(5): 691-701.

Lins, H.F. and Slack, J.R. (1999). Streamflow trends in the United States. Geophysical Research Letters 26(2): 227-230.

Lorenzo-Seva, U. (2013). How to report the percentage of explained common variance in exploratory factor analysis. Technical Report. Department of Psychology, Universitat Rovira i Virgili, Tarragona.

NOAA Climate Prediction Center, Climate Teleconnections. Retrieved from http://www.cpc. ncep.noaa.gov/data/teledoc/teleintro.shtml

Pal, I., Anderson B.T., Salvucci G.D., Gianotti D.J. (2013). Shifting seasonality and increasing w frequen cy of precipitation in wet and dry seasons across the US. Geophysical Research Letters 40:4030-4035.

Pal, I., Towler E., and Livneh B., (2015). How Can We Better Understand Low River Flows as Climate Changes?, Earth \& Space Science News. Retrieved from https://eos. org/opinions/how-can-we-better-understand-low-river-flows-as-climate-changes

Small, D., et al. (2006). Trends in precipitation and streamflow in the eastern U.S.: Paradox or perception? Geophysical Research Letters 33(3): n/a-n/a.53.

Smakhtin, V.U. (2001). Low flow hydrology: a review. Journal of Hydrology 240(3-4): 147-186. 
Sawaske, S.R. and Freyberg, D.L. (2014). An analysis of trends in baseflow recession and low-flows in rain-dominated coastal streams of the pacific coast. Journal of Hydrology 519, Part A: 599-610.

Smith, I.L., (2002). A tutorial on Principal Components Analysis. Cornell University, USA.

Smith, C.L., Turcotte, L.D., and Isacks, L.B. (1998). Stream flow characterization and feature detection using a discrete wavelet transform Hydrological Processes, Vol. 12, $233 \pm 249$ (1998)

Tallaksen, L.M., and Van Lanen, H.A. (2004). Hydrological drought: processes and estimation methods for streamflow and groundwater. Elsevier 48.

Trenberth, K. E., et al. (2014). Global warming and changes in drought. Nature Clim Change 4 (1): 17-22.

U.S. EPA (2012) Background information on the definition and characteristics of low flows. Flow 101. DFLOW. Retrieved from http://water.epa.gov/scitech/datait/models/dflow/ flow101.cfm

USGS GAGES-II: Geospatial Attributes of Gages for Evaluating Streamflow. Retrieved from http://water.usgs.gov/GIS/metadata/usgswrd/XML/gagesII_Sept2011.xml

USGS Water Data FAQ. Retrieved from http://help.waterdata.usgs.gov/faq/sites/do-stationnum bers-have-any-particular-meaning.

Westra, S., Brown, C., Lall, U., and Sharma A. (2007). Modeling multivariable hydrological series: Principal component analysis or independent component analysis?. Water Resources. Res., 43, W06429, doi:10.1029/2006WR005617. 


\section{Extended Turkish Abstract (Genişletilmiş Türkçe Özet)}

\section{Amerika Birleşik Devletleri’ndeki Minimum Akım Trendleri}

Dünya Meteoroloji Örgütü'nün tanımına göre minimum akım; kurak mevsimdeki süre boyunca nehirdeki suyun akışıdır. İzin verilebilen deşarj limitlerini belirlemek için istatistiksel hesaplamalarda 7 günlük ve 30 günlük en düşük akım değerleri kullanılmaktadır.

Kuraklık kavramının belirleyici faktörlerinden olan minimum akım, ayrıca su kaynaklarının yönetimi için de oldukça önemli bir unsurdur. Ülkedeki su kaynaklarının sahip olduğu minimum akım davranışı ve eğilimleri, gelecek için karar oluşturma ve etkin planlama gibi stratejik öneme sahip süreçlerde kullanılabilecek bilgilerdir. Minimum akımın uzun vadeli olarak birbirini takip etmesi sonucunda kronik su kıtlığ1 oluşabilir. Su kıtlığı; bölgedeki kullanılabilecek su kaynaklarının talep edilen miktarı karşılayamamasından dolayı ortaya çıkan bir sorundur. Bahsedilen su kıtlığı sorunu ise ülkedeki sosyal ve ekonomik yapıyı önemli ölçüde etkileyen etkenlerden birisidir. Talep edilen su miktarının karşılanamaması, ülke ekonomisine katkıda bulunan tarımsal ve endüstriyel üretimi olumsuz etkileyeceği gibi temel insan ihtiyaçları arasında olan evsel su kullanımının karşılanmasının da zorlaştırmaktadır.

Bu çalışma; iklim değişikliği ve antropojenik etkilere maruz kalan tüm bölgeler ile sürdürülebilir yönetim adaptasyonu uygulanabilecek diğer bölgeleri kapsamaktadır. Ülkedeki minimum akım trendleri Birleşik Devletler Jeoloji Kurumu (United States Geological Survey USGS) nun akım gözlem istasyon verileri kullanılarak hesaplanmıştır. Akım gözlem istasyonları; insan aktivitelerine maruz kalmış (antropojenik) ve bu aktivitelerden etkilenmemiş olarak iki ayrı kategoriye ayrılıp incelenmiş ve trend karşılaştırma analizi yapılmıştır. Karşılaştırma analizi sonuçları sayesinde ülke genelindeki minimum akım eğilimlerinin, antropojenik aktivitelerden etkilenip etkilenmediğini ve doğal bir döngüye dahil olup olmadığı incelenmiştir.

Gerçekleştirilen minimum akım trend analizleri parametrik olmayan Mann-Kendall ve Sen-Slope trend testleri kullanılarak değerlendirilmiştir. Birleşik Devletler Jeoloji Kurumunun, toplamda 727 adet akım gözlem istasyonunun verileri \%95 önem düzeyi kullanılarak analiz edilmiştir. Bahsi geçen 727 adet akım gözlem istasyonunun her biri 80 yıllık günlük minimum akım verisine sahip olup istasyonların günlük verileri; 7 günlük ve 30 günlük minimum akım verilerine dönüştürüldükten sonra Mann-Kendall ve Sen-Slope Trend testleri uygulanmıştır. Parametrik olmayan bu istatistiksel testlere göre Birleşik Devletler genelinde minimum akım için artan yönde bir trend tespit edilmiştir.

Antropojenik etkilere maruz kalan akım gözlem istasyonları ile bu etkilere maruz kalmamış olan akım gözlem istasyonları trend karşılaştırma analizi sonucunda; antropojenik etkilere maruz kalmış olan istasyonlardaki istatistiksel olarak önem arz eden akım trend yüzdelerinin, etkiye maruz kalmamış olan akım gözlem istasyonlarına oranla daha yüksek olduğu bulunmuştur. 
Bahsedilen trend analizlerinin dişında, Dalgacık Dönüşümü (Wavelet Analysis), Temel Bileşen Analizi (Principle Component Analysis - PCA) ve Kümeleme Analizi (Clustering Analysis) de 80 yıllık günlük minimum akım verisine sahip olan 727 adet akım gözlem istasyonuna uygulanmıştır. Uygulanan bu analizler ile minimum akım büyüklüğü ve süreksizlikler tespit edilmiştir. Ayrıca, Birleşik Devletler genelinde benzer minimum akım trendleri ve özellikleri gösteren istasyonlar gruplandırılmıştır. Bu sayede ülke genelinde, benzer yıllık minimum akım yapısına sahip olan akım gözlem istasyonlarının bulunduğu bölgeler coğrafi olarak tespit edilmiştir. Tüm akım gözlem istasyonları ise kümeleme analizi sonuçlarına göre kendi içerisinde 7-günlük minimum akım için 5 ana gruba; 30 günlük minimum akım için ise 6 ana gruba ayrılmaktadır. Analizler aynı zamanda antropojenik etkiye maruz kalan ve maruz kalmamış olan gözlem istasyonları için de uygulanıp karşılaştırma yapılmıştır. Antropojenik etkiye maruz kalmayan doğal ortamdaki akım gözlem istasyonları gruplandırmada, antropojenik etkiye maruz kalan istasyonlara göre çok daha homojen bir dağılım göstermektedir.

Temel bileşen analizi (PCA) sonuçları Mann-Kendall ve Sen-Slope Trend testi sonuçlarını desteklemekte olup, birinci bileşenin (PC-1) zaman serileri yıllık minimum akım verilerinin değişkenliğini karakterize etmektedir. Dalgacık Dönüşümü (Wavelet) Analizi ise zaman serilerindeki minimum akım olayı dağılımını tespit ederek dalgacık spektral şeklini ortaya çıkarmaktadır.

Son olarak; minimum akım ile iklim değişikliği bileşenleri arasındaki uygunluk analizi yapılarak minimum akım davranışının iklim değişikliği ve diğer kuraklık indikatörleri ile bağlantısını dikkate alıp daha detaylı bir çalışma yapılabilir. Çalışmanın sonucunda tespit edilen insan etkilerine maruz kalan istasyonlardaki eğilim yüzdesinin etkilere maruz kalmayanlara oranla daha yüksek olması, su kaynaklarının insan etkileri sonucu oluşan çevresel değişiklerden ve iklim değişikliğinden etkilendiğini göstermektedir. 